Gut, 1963, 4, 368

\title{
A study of some factors affecting the mortality rate in diffuse peritonitis
}

\author{
J. L. DAWSON \\ From St. James's Hospital, Balham, London
}

EDITORIAL SYNOPSIS The results of a retrospective analysis of the records of 665 consecutive patients with diffuse peritonitis emphasize the considerable effect age and causal lesion have on the prognosis. The comparison of results of any innovations in the treatment of diffuse peritonitis cannot be assessed unless these factors are fully taken into account. The fallacy of comparing overall mortality figures is demonstrated. The high mortality rate for diffuse peritonitis associated with diverticulitis is noted.

Diffuse peritonitis is a common cause of death. According to the Registrar General it caused 4,311 deaths in England and Wales in 1958. Recent estimates of overall mortality have varied from 'less than 10\%' (Till, 1954) to 33.3\% (Menzies, 1961). In view of this discrepancy a retrospective analysis of the records of 665 consecutive cases of diffuse peritonitis was undertaken to investigate factors affecting the mortality rate, with special reference to the patient's age and the underlying causal lesion.

\section{CRITERIA FOR INCLUSION IN SERIES AND METHOD OF TREATMENT}

DEFINITION The term 'generalized' peritonitis implies every part of the peritoneal cavity being involved; this can only be verified at necropsy and consequently the term 'diffuse' perit_nitis seems a better one. Grey Turner (1938) pointed out that in the absence of local abscess formation, once the nidus of infection has spread from the primary lesion and caused a purulent exudate, then the case is one of unlimited peritonitis. Thus any patient reported to have free purulent fluid in the peritoneal cavity has been included in this series.

PATIENTS STUDIED The records of 665 consecutive cases of diffuse peritonitis admitted to a general hospital were studied. The figures include those brought in dead or moribund and diagnosed only at necropsy. Two large mental institutions provided some of the patients. Because of the difficulty of diagnosis in the mentally ill this group may have adversely affected the results. All patients lived within a few miles of the hospital and would be admitted within two hours of the diagnosis of an abdominal emergency being made.

CAUSAL LESIONS Patients were divided into subgroups depending upon the causal lesion of the diffuse peritonitis.

AGE The effect of age was studied by dividing patients into subgroups by decades.

SEX The results for each sex have been recorded separately.

LENGTH OF HISTORY It was hoped to correlate the length of history with the mortality rate, but to decide exactly when peritonitis had supervened would have been guesswork in many cases, and in many of the older patients the history was often sketchy or non-existent.

METHOD OF TREATMENT All patients diagnosed during life were given parenteral chemotherapy, usually penicillin and streptomycin; this was coupled with naso-gastric suction and intravenous fluids. Operative treatment of the causal lesion was carried out whenever possible. Appendicitis was treated by appendicectomy (and drainage in some cases). Gastric resection was carried out for almost all perforated gastric ulcers and chronic duodenal ulcers. Simple suture was reserved for perforated acute duodenal ulcers and very unfit patients. 'Perforated' diverticulitis coli was treated by transverse colostomy and drainage of the area of inflamed bowel. 
TABLE I

CAUSES OF DIFFUSE PERITONITIS IN 665 CONSECUTIVE PATIENTS (1953-59)

\begin{tabular}{lr} 
Diagnosis & No. of Patients \\
\hline Appendicitis & 246 \\
Perforated duodenal ulcer & 251 \\
Perforated gastric ulcer & 43 \\
Perforated diverticulitis coli & 28 \\
& \\
Miscellaneous & 12 \\
Primary & 12 \\
Cholecystitis & 10 \\
Perforated stomal ulcer & 9 \\
Perforated carcinoma of stomach & 9 \\
Post-operative & 8 \\
Perforated stercoral ulcer of large bowel & 6 \\
Perforated carcinoma of rectum & 5 \\
Perforation of ileum by foreign body & 4 \\
Salpingitis & 3 \\
Perforated mesenteric thrombosis & 3 \\
Ruptured bladder & 3 \\
Perforated Meckel's diverticulum & 3 \\
Acute pancreatitis & 2 \\
Perforated entero-colitis & 2 \\
Perforated volvulus of sigmoid & 2 \\
Perforated strangulated femoral hernia & 2 \\
Perforated jejunal diverticulum & 1 \\
Leaking infected ovarian cyst & 1 \\
Primary biliary & 665 \\
&
\end{tabular}

RESULTS

The causes of diffuse peritonitis in the 665 patients studied are shown in Table I. As might be expected over one-third of the cases were due to appendicitis and about another third due to perforated duodenal ulcer. The ratio of perforated duodenal ulcers to perforated gastric ulcers was $5 \cdot 8: 1$. In Table I the less common causal lesions are listed, but as there were such small numbers of each of them separate analysis would not produce statistically significant results; therefore they have been grouped in sub- sequent tables under the heading miscellaneous. Although the term perforated diverticulitis coli is used, an actual perforation was not always found.

In Table II the age distribution of the patients is shown for each group. The figures are given separately for each sex. The preponderance of male patients is largely accounted for by the large number of males with perforated duodenal ulcer. The sex ratio in the other conditions was approximately equal. Apart from patients with appendicitis the majority were aged over 40 years.

The mortality rate for each group is shown in Table III. The figures are given separately for each sex and each decade. The overall mortality rate, ignoring sex, age, and the causal lesion, was $19 \cdot 5 \%$. But mortality rises with age and below the age of 40 years the mortality is negligible. The difference between the mortality rate in the two sexes is not striking. The mortality rates for the three largest groups, i.e., all cases, appendicitis with diffuse peritonitis, and perforated duodenal ulcers, are shown in Figures 1, 2, and 3. In appendicitis there is little rise in mortality rate with age; this differs considerably from all the other groups. There is no striking difference in mortality between the sexes. The overall mortality for appendicitis with diffuse peritonitis was $3.6 \%$. In perforated duodenal ulcers mortality rose steeply after the age of 60 years. The mortality rate in women was considerably higher then in men. The overall mortality in this group was $15.5 \%$. The number of perforated gastric ulcers is comparatively small, but mortality rises steeply with age and is much higher than that for perforated duodenal ulcer in all age groups. The mortality in females was less than in males. The overall mortality for this group was $46.5 \%$. The results for diverticulitis are unexpected in that the mortality of male

TABLE II

AGE AND SEX DISTRIBUTION OF 665 PATIENTS WITH DIFFUSE PERITONITIS

\begin{tabular}{|c|c|c|c|c|c|c|c|c|c|c|c|}
\hline \multirow[t]{2}{*}{ Diagnosis } & \multirow[t]{2}{*}{ Sex } & \multicolumn{9}{|c|}{ Age in Years } & \multirow[t]{2}{*}{ Total } \\
\hline & & $0-9$ & $10-19$ & $20-29$ & $30-39$ & $40-49$ & $50-59$ & $60-69$ & $70-79$ & $80-89$ & \\
\hline Appendicitis & $\begin{array}{l}\text { Male } \\
\text { Female }\end{array}$ & $\begin{array}{l}24 \\
20\end{array}$ & $\begin{array}{l}31 \\
15\end{array}$ & $\begin{array}{r}14 \\
4\end{array}$ & $\begin{array}{l}15 \\
13\end{array}$ & $\begin{array}{r}15 \\
9\end{array}$ & $\begin{array}{l}20 \\
14\end{array}$ & $\begin{array}{l}11 \\
13\end{array}$ & $\begin{array}{r}5 \\
11\end{array}$ & $\begin{array}{l}4 \\
9\end{array}$ & $\begin{array}{l}139 \\
107\end{array}$ \\
\hline Perforated duodenal ulcer & $\begin{array}{l}\text { Male } \\
\text { Female }\end{array}$ & - & - & $\begin{array}{r}17 \\
3\end{array}$ & 28 & $\begin{array}{r}40 \\
5\end{array}$ & $\begin{array}{r}53 \\
5\end{array}$ & $\begin{array}{r}43 \\
4\end{array}$ & $\begin{array}{r}36 \\
6\end{array}$ & $\begin{array}{l}8 \\
1\end{array}$ & $\begin{array}{r}227 \\
24\end{array}$ \\
\hline Perforated gastric ulcer & $\begin{array}{l}\text { Male } \\
\text { Female }\end{array}$ & - & - & - & 1 & $\begin{array}{l}1 \\
1\end{array}$ & $\begin{array}{l}7 \\
2\end{array}$ & $\begin{array}{l}9 \\
1\end{array}$ & $\begin{array}{r}8 \\
10\end{array}$ & $-\frac{}{3}$ & $\begin{array}{l}26 \\
17\end{array}$ \\
\hline Perforated diverticulitis coli & $\begin{array}{l}\text { Male } \\
\text { Female }\end{array}$ & - & - & - & 1 & 1 & $\begin{array}{r}4 \\
-\end{array}$ & $\begin{array}{l}6 \\
6\end{array}$ & $\overline{9}$ & $\overline{1}$ & $\begin{array}{l}12 \\
16\end{array}$ \\
\hline Miscellaneous & $\begin{array}{l}\text { Male } \\
\text { Female }\end{array}$ & $\begin{array}{l}1 \\
2\end{array}$ & $\begin{array}{l}1 \\
1\end{array}$ & $\begin{array}{l}1 \\
2\end{array}$ & $\begin{array}{l}1 \\
3\end{array}$ & $\begin{array}{r}9 \\
-\end{array}$ & $\begin{array}{r}16 \\
5\end{array}$ & $\begin{array}{r}10 \\
8\end{array}$ & $\begin{array}{l}11 \\
15\end{array}$ & $\begin{array}{l}6 \\
5\end{array}$ & $\begin{array}{l}56 \\
41\end{array}$ \\
\hline Total & $\begin{array}{l}\text { Male } \\
\text { Female }\end{array}$ & $\begin{array}{l}25 \\
22\end{array}$ & $\begin{array}{l}34 \\
15\end{array}$ & $\begin{array}{r}32 \\
9\end{array}$ & $\begin{array}{l}46 \\
16\end{array}$ & $\begin{array}{l}66 \\
15\end{array}$ & $\begin{array}{r}100 \\
26\end{array}$ & $\begin{array}{l}79 \\
32\end{array}$ & $\begin{array}{l}60 \\
51\end{array}$ & $\begin{array}{l}18 \\
19\end{array}$ & $\begin{array}{l}460 \\
205\end{array}$ \\
\hline
\end{tabular}


TABLE III

MORTALITY PER CENT OF PATIENTS WITH DIFFUSE PERITONITIS (1953-59)

\begin{tabular}{|c|c|c|c|c|c|c|c|c|c|c|c|}
\hline \multirow[t]{2}{*}{ Diagnosis } & \multirow[t]{2}{*}{ Sex } & \multicolumn{9}{|c|}{ Age in Years } & \multirow[t]{2}{*}{ Total } \\
\hline & & 0.9 & $10-19$ & $20-29$ & $30-39$ & $40-49$ & $50-59$ & $60-69$ & $70-79$ & $80-89$ & \\
\hline Appendicitis & $\begin{array}{l}\text { Male } \\
\text { Female }\end{array}$ & $\begin{array}{l}4 \cdot 1 \\
0\end{array}$ & $\begin{array}{l}0 \\
0\end{array}$ & $\begin{array}{l}0 \\
0\end{array}$ & $\begin{array}{l}6 \cdot 6 \\
0\end{array}$ & $\begin{array}{r}6 \cdot 6 \\
11 \cdot 1\end{array}$ & $\begin{array}{l}0 \\
7 \cdot 1\end{array}$ & $\begin{array}{l}9 \cdot 1 \\
0\end{array}$ & $\begin{array}{l}\mathbf{0} \\
\mathbf{0}\end{array}$ & $\begin{array}{l}50 \\
12 \cdot 3\end{array}$ & $\begin{array}{l}4.3 \\
2.8\end{array}$ \\
\hline Perforated duodenal ulcer & $\begin{array}{l}\text { Male } \\
\text { Female }\end{array}$ & - & $\underline{0}$ & $\begin{array}{l}\mathbf{0} \\
\mathbf{0}\end{array}$ & $\frac{3 \cdot 5}{-}$ & $\begin{array}{l}0 \\
0\end{array}$ & $\begin{array}{l}5 \cdot 6 \\
0\end{array}$ & $\begin{array}{l}18 \cdot 6 \\
75\end{array}$ & $\begin{array}{l}44 \cdot 4 \\
50\end{array}$ & $\begin{array}{l}62 \cdot 5 \\
-\end{array}$ & $\begin{array}{l}14.5 \\
25\end{array}$ \\
\hline Perforated gastric ulcer & $\begin{array}{l}\text { Male } \\
\text { Female }\end{array}$ & $\overline{-}$ & 二 & $\overline{-}$ & $\underline{0}$ & $\begin{array}{l}\mathbf{0} \\
0\end{array}$ & $\begin{array}{c}14 \cdot 2 \\
0\end{array}$ & $\begin{array}{c}44 \cdot 4 \\
100^{1}\end{array}$ & $\begin{array}{l}87 \cdot 5 \\
50\end{array}$ & $\overline{66.6}$ & $\begin{array}{l}46 \cdot 1 \\
46 \cdot 9\end{array}$ \\
\hline Perforated diverticulitis coli & $\begin{array}{l}\text { Male } \\
\text { Female }\end{array}$ & $\overline{-}$ & 二 & - & $\underline{0}$ & $\frac{100^{x}}{-}$ & $\frac{25}{-}$ & $\begin{array}{l}16 \cdot 6 \\
50\end{array}$ & $\overline{66.6}$ & $\overline{100^{1}}$ & $\begin{array}{l}25 \\
62.5\end{array}$ \\
\hline Miscellaneous: & $\begin{array}{l}\text { Male } \\
\text { Female }\end{array}$ & $\begin{array}{l}0 \\
0\end{array}$ & $\begin{array}{c}100^{1} \\
0\end{array}$ & $\begin{array}{l}0 \\
0\end{array}$ & $\begin{array}{c}100^{1} \\
0\end{array}$ & $\begin{array}{l}33 \cdot 3 \\
-\end{array}$ & $\begin{array}{l}37 \cdot 5 \\
60\end{array}$ & $\begin{array}{l}60 \\
37 \cdot 5\end{array}$ & $\begin{array}{l}81 \cdot 8 \\
46.6\end{array}$ & $\begin{array}{c}83 \cdot 3 \\
100\end{array}$ & $\begin{array}{l}55 \cdot 3 \\
4 \cdot 39\end{array}$ \\
\hline Total & $\begin{array}{l}\text { Male } \\
\text { Female }\end{array}$ & $\begin{array}{l}4 \\
0\end{array}$ & $\begin{array}{l}2 \cdot 9 \\
0\end{array}$ & $\begin{array}{l}0 \\
0\end{array}$ & $\begin{array}{l}6 \cdot 5 \\
0\end{array}$ & $\begin{array}{l}7.5 \\
6.6\end{array}$ & $\begin{array}{c}11 \\
15 \cdot 3\end{array}$ & $\begin{array}{l}25 \cdot 3 \\
31 \cdot 2\end{array}$ & $\begin{array}{l}53 \cdot 3 \\
43 \cdot 1\end{array}$ & $\begin{array}{l}66 \cdot 6 \\
47 \cdot 7\end{array}$ & $\begin{array}{l}18.6 \\
21.9\end{array}$ \\
\hline
\end{tabular}

'One patient only in this decade

patients in the sixth decade was less than that in the fifth decade. This is probably explained by the small number (28 patients) in this group. The overall mortality was $46.6 \%$. The miscellaneous group is an artificial one not strictly comparable with the other groups. However, it demonstrated the rising mortality rate with increasing age and the overall rate was $50.5 \%$.

\section{DISCUSSION}

Menzies (1961) discussing diffuse peritonitis states that the mortality rate in one large hospital had doubled in the past 10 years. The latest overall mortality rate he quotes is $33.3 \%$. He suggests that one of the main factors involved may be the emergence of ever increasing numbers of resistant bacteria. However, as there is no breakdown for age, sex, or diagnosis it is not clear whether this increased mortality rate is real or apparent.

A study of the results obtained in the present series immediately shows the fallacy that may be present when overall figures are discussed. The age of the patient appears to have the most consistent and profound effect on the prognosis of diffuse peritonitis (Figs. 1 and 3). A good analogy is afforded by the mortality rate in gastroduodenal haemorrhage. Avery Jones (1960) pointed out the difficulty of comparing mortality rates in patients with gastroduodenal haemorrhage unless the age distribution of the patients is known He showed that over the age of 60 years the mortality rate for gastroduodenal haemorrhage rises steeply. He refers to the 'inevitable mortality' in persons over 60 due to multiple pathological processes proceeding concomitantly, usually one or more, of chronic bron- chitis and emphysema, myocardial ischaemia, cerebral atherosclerosis, or prostatic obstruction. The different mortality rates for perforated duodenal ulcer and appendicitis with peritonitis are shown clearly in Figures 2 and 3. Figure 1 (representing the results for all 665 cases) shows a different pattern from Figs. 2 and 3, suggesting that the prognosis of diffuse peritonitis is greatly affected by the causal lesion; thus any discussion or comparison of overall figures is likely to be fallacious.

Diffuse peritonitis secondary to appendicitis shows the lowest mortality rates of all groups and compares favourably with other series. Grey Turner (1938) quoted an overall mortality rate of $29.2 \%$ in 96 cases. Hawk, Becker, and Lehman (1950) quote a mortality rate of $7.5 \%$ in 80 cases. Rees (1952) quotes a mortality rate of $12 \%$ in 16 cases. None of these authors gives the age incidence of the patients studied. It is generally conceded that the mortality rate is lower than 20 years ago, though it is difficult to find strictly comparable groups to show this. The comparatively low mortality rate is probably due to a number of factors: the causal lesion is completely removed (c.f. diverticulitis); there is a gradual invasion of the peritoneal cavity $(c . f$., perforated peptic ulcer). The operation is usually carried out through a McBurney incision which probably has fewer complications than a paramedian or midline incision (Allen, 1937; Taylor and Hodges, 1941).

The treatment of perforated duodenal and gastric ulcers by gastric resection has been discussed by Lowden (1952) and by Desmond and Seargeant (1957). Although no decrease in mortality has been shown there is a decreased morbidity in the short- and longterm follow-ups. Kozoll and Meyer (1960) carefully analysed 719 patients with perforated gastric ulcers 


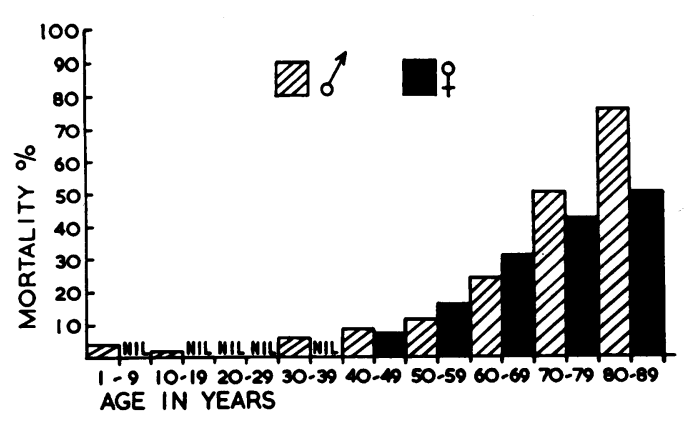

FIG. 1. The percentage mortality of 665 consecutive patients with diffuse peritonitis 1953-59.

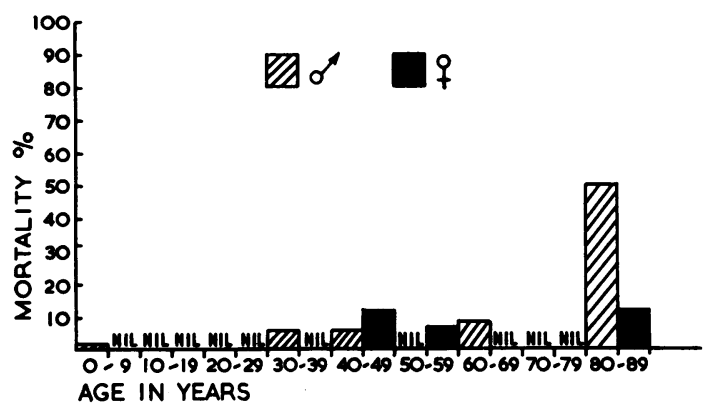

FIG. 2. The percentage mortality of 246 patients with diffuse peritonitis secondary to appendicitis.

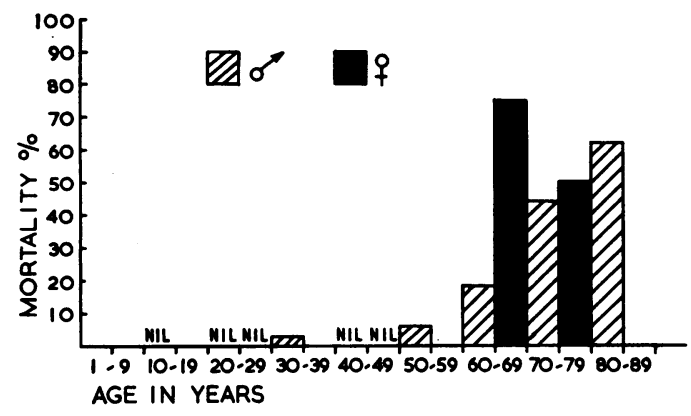

FIG. 3. The percentage mortality of 251 patients with diffuse peritonitis secondary to perforated duodenal ulcer.

and 1,185 patients with perforated duodenal ulcers. They showed the effect of age, sex, and the diagnosis on the prognosis. As in the present study, they found that at all ages and in both sexes perforated gastric ulcer had a much higher mortality rate than perforated duodenal ulcer. The mortality rate among females was higher in all age groups. This shows the fallacy of grouping gastric and duodenal perforations together for comparative purposes. Unlike this series the mortality rate in perforated duodenal ulcers rose from the third decade onward, whereas in the present study the rise occurs in the sixth decade. It is interesting to note the ratio of perforated duodenal to gastric ulcers was 1.6:1 compared with 5:8.1 in the present study. Rogers (1960) does not distinguish between gastric and duodenal ulcer patients but confirms the rising mortality with age and the increased mortality in female patients.

The mortality rate from perforated diverticulitis is high, and although the present series is small (28 cases), previous authors have usually had similar numbers. Smithwick (1942) quoted 42 cases, Brown and Toomey (1960) 41 cases, and Bevan (1961) 23 cases. They all emphasized the high mortality rate but gave no breakdown for age. Thus, because of the small numbers it is very difficult to assess the results of clinical trials or alternative methods of treatment. The more aggressive approach advocated by some authors (Babington, 1948; Brown and Toomey, 1960) towards uncomplicated diverticulitis has much to recommend it in view of the high morbidity and mortality caused by the complications. However, some of our patients denied any history of bowel trouble; thus such a policy would have only a limited effect on the prevention of such complications as diffuse peritonitis. The present method of treatment of diffuse peritonitis secondary to diverticulitis coli by transverse colostomy and drainage of the inflamed bowel is not always effective. As Smithwick (1942) points out, despite a proximal defunctioning colostomy, the phlegmon of diverticulitis is self-perpetuating in some $25 \%$ of patients. Ryan (1958) successfully performed resection and end-to-end anastomosis in four patients; however, this method could not be recommended in all patients, especially the very ill, obese patient. Perhaps a modified Hartmann's operation might be worth a trial; this would remove the origin of the infection and avoid the necessity of any colonic anastomosis. Sames (1961) has used this method for dealing with obstructed carcinoma of the left colon, with great success.

I should like to thank Mr. N. C. Tanner, Mr. A. M. Desmond, and Mr. J. Burke for permission to study their patients.

\section{REFERENCES}

Allen, P. D. (1937). Acute appendicitis in children. J. Amer. med. Ass., 109, 121-125.

Babington, S. H. (1948). Diverticulitis of the colon: a plea for early surgical intervention. J. int. Coll. Surg., 11, 504-510.

Bevan, P. G. (1961). Acute diverticulitis: a review of emergency admissions. Brit. med. J., 1, 400-404.

Brown, D. B., and Toomey, W. F. (1960). Diverticular disease of the colon. Brit. J. Surg., 47, 485-493.

Desmond, A. M., and Seargeant, P. W. (1957). The place of primary gastric resection in the treatment of perforated peptic ulcer. Ibid., 45, 283-286.

Hawk, J. C. Jr., Becker, W. F., and Lehman, E. P. (1950). Acute appendicitis III. Ann. Surg., 132, 729-745.

Jones, F. Avery (1960). Gastro Intestinal Haemorrhage. In Clinical Gastro-enterology, edited by F. A. Jones and J. W. P. Gummer pp. 421-424. Blackwell, Oxford. 
Kozoll, D. D., and Meyer, K. A. (1960). General factors influencing the incidence and mortality of acute perforated gastroduodenal ulcers. Surg. Gynec. Obstet., 111, 607-625.

Lowdon, A. R. (1952). The treatment of acute perforated peptic ulcer by primary partial gastrectomy. Lancet, 1, 1270-1274.

Menzies, T. (1961). The Management of Peritonitis. In Modern Trends in Gastro-enterology, (3rd series), edited by W. I. Card, pp. 127157. Butterworth, London.

Rees, W. S. (1952). Fatal appendicitis: the decline in mortality. Lancet, 2, 1199-1203.

Rogers, F. A. (1960). Factors affecting the mortality from acute gastroduodenal perforation. Surg. Gynec. Obstet., 111, 771778 .
Ryan, P. (1958). Emergency resection and anastomosis for perforated sigmoid diverticulitis. Brit. J. Surg., 45, 611-616.

Sames, C. P. (1961). Resection of carcinoma of the colon in the presence of obstruction. Proc. roy. Soc. Med., 54, 725-726.

Smithwick, R. H. (1942). Experiences with the surgical management of diverticulitis of the sigmoid. Ann. Surg., 115, 969-985.

Taylor, E. S., and Hodges, R. G. (1941). Acute appendicitis in children. Surg. Gynec. Obstet., 73, 288-300.

The Registrar General's Statistical Review of England and Wales for the year 1958, London, H.M.S.O., 1960.

Till, A. S. (1954). General Peritonitis in Progress in Clinical Surgery, edited by R. Smith, pp. 129-145. Churchill, London.

Turner, G. Grey (1938). Acute appendicitis. Brit. med. J., 2, 691-695.

\section{The September 1963 Issue}

\section{THE SEPTEMBER 1963 ISSUE CONTAINS THE FOLLOWING PAPERS}

A clinical study of chronic pancreatitis OLIVER FITZGERALD, PATRICK FITZGERAID, JAMES FENNELLY, JOSEPH P. MCMULLIN, and SYLVESTER J. BOLAND

Pancreatic replacement therapy in the treatment of pancreatic steatorrhoea I. N. MARKS, S. BANK, and EVELYN M. AIRTH

Post-necrotic cirrhosis with chronic cholestasis D. V. DATTA, SHEILA SHERLOCK, and PETER J. SCHEUER

The vitamin B12 content of human liver tissue obtained by aspiration biopsy R. A. JOSKE

The electrophoretic pattern of normal human gastric juice and of the gastric juice of patients with gastric ulcer and gastric cancer D. W. PIPER, M. C. STIEL, and J. E. BUILDER
An assessment of the augmented histamine test in the diagnosis of peptic ulcer J. H. BARON

The absorption of oleic acid in the bile fistula rat D. R. SAUNDERS and A. M. DAWSON

Use of labelled triolein, vitamin A, and D-xylose in the diagnosis of malabsorption $\mathbf{K}$. G. WORMSLEY

The clinical features of haemorrhage from diverticula of the colon M. W. F. DUNNING

Adult coeliac disease W. T. COOKE, D. J. FONE, E. V. COX, M. J. MEYNELL, and R. GADDIE

Acute folic acid deficiency of unknown aetiology: temperate sprue W. T. COOKE, D. J. FONE, E. V. COX, M. J. MEYNELL, and R. GADDIE

Copies are still available and may be obtained from the PUBLISHING MANAGER, BRITISH MEDICAL ASSOCIATION, TAVISTOCK SQUARE, W.C.I., price 18s. 6D. 